Political Analysis (ISSN 1047-1987; EISSN 1476-4989) is published quarterly in January, April, July, and October as the official journal of the Society for PoliticalMethodology. The journal is published by Cambridge University Press. Postmaster: send address changes to Political Analysis, Cambridge University Press, One Liberty Plaza, New York, NY 10006, USA.

\title{
Instructions for Authors
}

Authors interested in submitting to Political Analysis should consult the instructions for contributors available on the Political Analysis website (www.cambridge.org/core/journals/political-analysis). All submissions should be made online through the Political Analysis ScholarOne system (mc.manuscriptcentral.com/pa).

\section{Subscriptions}

A subscription to Political Analysis comprises 4 issues. The subscription price of Volume 30 (2022) including delivery by air where appropriate (but excluding VAT), is $\$ 804.00$ ( $£ 538.00$ ) for institutions print and online; $\$ 756.00$ $(£ 502.00)$ for institutions print only; and $\$ 621.00$ ( $£ 415.00)$ for institutions online only. The rate for individuals is $\$ 137$ (£98) for print only and $\$ 99$ (£71) for online only.

Orders, which must be accompanied by payment, may be sent to a bookseller, subscription agent or direct to the publisher: Cambridge University Press, Journals Fulfilment Department, One Liberty Plaza, New York, NY 10006, USA; or Cambridge University Press, University Printing House, Shaftesbury Road, Cambridge CB2 8BS, UK. Alternatively, you can place an order online at www.cambridge.org/core/journals/political-analysis.

For single issues, please contact: customer_service@cambridge.org.

\section{Advertising}

For information on display ad sizes, rates, and deadlines for copy, please visit the journal homepage at www.cambridge.org/core/journals/political-analysis or contact ad_sales@cambridge.org.

Copyright (C) The Society for Political Methodology 2022. All rights reserved. No part of this publication may be reproduced, in any form or by any means, electronic, photocopying, or otherwise, without permission in writing from Cambridge University Press. Policies, request formsand contacts are available at: http://www.cambridge.org/ about-us/rights-permissions.

Permission to copy (for users in the U.S.A.) is available from Copyright Clearance Center http://www. copyright.com; Email: info@copyright.com. 


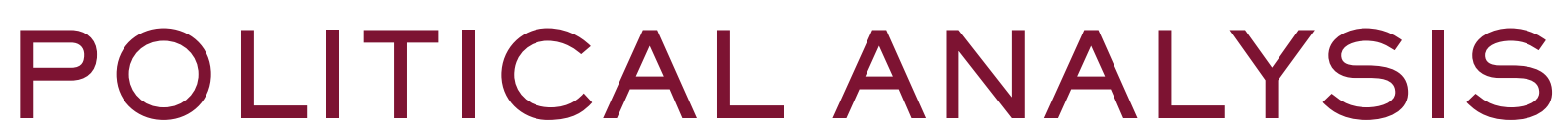

Volume 30 • Number 1 • January 2022

\section{ARTICLES}

Spikes and Variance: Using Google Trends to Detect and Forecast Protests Joan C. Timoneda and Erik Wibbels

Improving the External Validity of Conjoint Analysis: The Essential Role of Profile Distribution

Brandon de la Cuesta, Naoki Egami and Kosuke Imai

Understanding, Choosing, and Unifying Multilevel and Fixed Effect Approaches

Chad Hazlett and Leonard Wainstein
Accounting for Skewed or One-Sided Measurement Error in the Dependent Variable Daniel L. Millimet and Christopher F. Parmeter

Combining Outcome-Based and Preference-Based Matching: A Constrained Priority Mechanism

Avidit Acharya, Kirk Bansak and Jens Hainmueller

Learning to See: Convolutional Neural Networks for the Analysis of Social Science Data

Michelle Torres and Francisco Cantú

\section{LETTER}

Nonignorable Attrition in Pairwise Randomized Experiments

Kentaro Fukumoto

Do Name-Based Treatments Violate Information Equivalence? Evidence from a Correspondence Audit Experiment Michelangelo Landgrave and Nicholas Weller

\section{CORRIGENDUM}

Using Motion Detection to Measure Social Polarization in the U.S. House of Representatives - CORRIGENDUM Bryce J. Dietrich 